\author{
Multidisciplinary \\ SCIENTIFIC JOURNAL OF \\ MARITIME RESEARCH
}

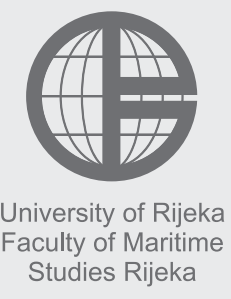

Multidisciplinarni

znanstveni časopis

POMORSTVO

\title{
Legal Challenges of Implementing the System of Monitoring Carbon Dioxide Emissions from Maritime Transport within Ports of Call under the Jurisdiction of EU Member States
}

\author{
Željka Primorac \\ Faculty of Law University of Split, Domovinskog rata 8, 21000 Split, Croatia, e-mail: zeljka.primorac@pravst.hr
}

\begin{abstract}
The subject analysed in this paper is European achievements and legal standards for the reduction of carbon dioxide $\left(\mathrm{CO}_{2}\right)$ emissions from maritime transport. The author re-examines the ecological aspect of European maritime navigation and its important role in reducing $\mathrm{CO}_{2}$ emissions as the most important greenhouse gas. By reviewing the sources of European law relevant to this matter, the author examines European legal origins based on the provisions of Regulation (EC) No. 2015/757 of the European Parliament and of the Council on the monitoring, reporting and verification of carbon dioxide emissions from maritime transport. In order to provide a systematic overview of the European legal framework, the author also analyses provisions that complement the rules and methods for monitoring $\mathrm{CO}_{2}$ emissions from maritime transport, i.e. the provisions contained in Regulation (EC) No. 2016/1927 and Regulation (EC) No. 2016/1928. The underlying concept of this paper is a discussion concerning the provisions of the regional monitoring, reporting and verification system of $\mathrm{CO}_{2}$ emissions from maritime transport, applicable to all ships irrespective of the flag the ship flies. The author further presents and analyses the effect that the application of the relevant provisions has on the reduction of $\mathrm{CO}_{2}$ emissions in ports and the measures that the European ports of call will be authorized to take, on $1^{\text {st }}$ July 2019, in the sense of checking the Document of Compliance of the ship with the provisions of Regulation (EC) No. 2015/757. Taking into account the justification and functionality of the regional approach to addressing $\mathrm{CO}_{2}$ emissions issues from ships, the author considers it necessary to achieve international uniformity in order to reduce $\mathrm{CO}_{2}$ emissions from maritime transport globally.
\end{abstract}

\author{
ARTICLE INFO \\ Preliminary communication \\ Received 21 November 2017 \\ Accepted 10 January 2018 \\ Key words: \\ $\mathrm{CO}_{2}$ emissions \\ Maritime transport \\ Ports of call \\ Regulation (EC) No. 2015/757
}

\section{Introduction}

Maritime transport is the most efficient form of transport of goods. $90 \%$ of international trade [1] and $74 \%$ of European trade [2] is transported by sea, and given the productivity of maritime transport, it is considered environmentally acceptable. However, maritime transport has a negative impact on air pollution from ships [3]. Maritime transport contributes to greenhouse gas emissions to a very low degree (10.6\%) [4] compared to other transport sectors (road transport - 74\%; air transport - 12.6\%; rail transport $-1.6 \%$; inland waterway transport $-1.1 \%$ ] [5], but a growing source of emissions are precisely the greenhouse gas emissions generated by international navigation [6]. By 2050, greenhouse gas emissions from maritime transport are expected to increase by $50-250 \%$ in pro- portion to the expected growth of international maritime trade [7] [8]. Data shows that in 1996 there were $419 \mathrm{mln}$ tonnes $\mathrm{CO}_{2}$ emisssions which present $1.5 \%$ share of total emissions [9]. In the EU, total greenhouse gas emissions decreased by 13\% in the period 2007-2012 (from 1095 million tonnes of $\mathrm{CO}_{2}$ to 949 million tonnes of $\mathrm{CO}_{2}$ ) [10] and by 2014, by another 4\% compared to the year 2013 . Nevertheless, in the joint energy and climate policy up to 2030 (2030 Energy Strategy) [11], the reduction of greenhouse gas emissions by $40 \%$ by the year 2030 is indicated as the target and the most cost effective turning point for the EU on the path towards a low-carbon economy. Furthermore, the EU's strategic goal is to achieve $80 \%$ $-95 \%$ reduction of greenhouse gas emissions by 2050 , compared to the 1990 levels. The efforts made to date by the EU to reduce greenhouse gas emissions (including 
carbon dioxide $-\mathrm{CO}_{2}$, the most important greenhouse gas, which contributes to greenhouse gas emissions with as much as $65 \%$ [12] e.g. $83.5 \%$ in the USA and $82 \%$ in the EU in 2010 [13] did not relate to the monitoring and reporting of greenhouse gas emissions from the maritime transport sector [14], since the intention was the compliance of measures and methods of reducing greenhouse gas emissions from maritime transport at the international level.

\section{The European Legal Framework for Monitoring $\mathrm{CO}_{2}$ Emissions from Maritime Transport}

Maritime transport results in emissions of nearly 100 million tonnes of $\mathrm{CO}_{2}$ per year and is responsible for about $2.2 \%$ of global $\mathrm{CO}_{2}$ emissions [15]. IMO Study on GHG Emissions from Ships from 2000 estimated 1.8\% contribution of the $\mathrm{CO}_{2}$ emission from maritime transport (about 420 mln tonnes of $\mathrm{CO}_{2}$ ) - to the global $\mathrm{CO}_{2}$ emission [16] and in 2007 this percentage has increased to $2.7 \%$ [17]. From 2005 to 2012, there was a $\mathrm{CO}_{2}$ emissions decrease for $11.5 \%$ so the Third IMO GHG Study from 2014 showed that shipping $\mathrm{CO}_{2}$ emissions in 2007 presented 3.5\%, in $2008-3.5 \%$, in $2009-3.1 \%$, in $2010-2.7 \%$, in $2011-$ $2.9 \%$, in $2012-2.6 \%$ of global $\mathrm{CO}_{2}$ emissions [18]. The overall $\mathrm{CO}_{2}$ emissions from international maritime shipping comprise $2.2 \%$ of the global $\mathrm{CO}_{2}$ emissions in 2014 [19].

$\mathrm{CO}_{2}$ emissions from international maritime navigation are expected to increase considerably (from 190 million tonnes in 2012 to 208 million tonnes in 2030) and $\mathrm{CO}_{2}$ emissions from EU maritime transport increased by $48 \%$ between 1990 and 2008 [20]. In the second IMO study on greenhouse gas emissions from 2009, it was published that, in 2007, the European maritime navigation contributed to $25-28 \%$ of $\mathrm{CO}_{2}$ emissions [21], estimating that it will have resulted in up to 250 million tonnes of $\mathrm{CO}_{2}$ by 2050. The EU 2011 White Paper on Transport [22] determines the target, by 2050, to reduce the emissions of greenhouse gases in maritime transport by at least $40 \%$ (as compared to the year 2005), that is, by at least $60 \%$ as compared to the year 1990 [23]. Although the EU requires a global approach to reducing greenhouse gas emissions generated by international navigation, in order to reduce $\mathrm{CO}_{2}$ emissions from maritime traffic at a cost-effective EUlevel, on $29^{\text {th }}$ April 2015, the European Parliament and the Council adopted the Regulation (EC) No. 2015/757 on the monitoring, reporting and verification of carbon dioxide emissions from maritime traffic, and amending Directive 2009/16/EC [24].

As a model for the implementation of a global monitoring, reporting and verification system of $\mathrm{CO}_{2}$ emissions from maritime traffic (hereinafter: MRV system) [25], Regulation (EC) No. 2015/757 has created a European legal framework [26] laying down the rules for accurate monitoring of $\mathrm{CO}_{2}$ emissions from ships arriving in ports under the jurisdiction of EU Member States, departing from ports or that are in ports (Art. 1. Regulation (EC) No. 2015/757). Pursuant to the provisions of Art. 2(1) of Regulation (EC) No. 2015/757, the mentioned Regulation also applies to ships above 5000 gross tonnage (they account for around $55 \%$ of the number of ships calling into EU ports and represent around $90 \%$ of the related emissions) [27] that are arriving in a port under the jurisdiction of an EU Member State, departing from a port of an EU Member State or are in a port under the jurisdiction of an EU Member State. Therefore, Regulation (EC) No. 2015/757 applies to ships irrespective of the flag they fly! For ships of less than 5000 gross tonnage, this Regulation does not apply because these ships, although accounting for around $40 \%$ of the fleet, contribute only $10 \%$ to the emissions. In addition, Regulation (EC) No. 2015/757 does not apply to warships, naval auxiliaries, fish-catching or fish-processing ships, wooden ships of a primitive build, ships not propelled by mechanical means, or government ships used for non-commercial purposes (Art. 2(2) Regulation (EC) No. 2015/757).

Pursuant to Art. 6(1) of Regulation (EC) No. 2015/757, companies (the shipowner or any other organisation or person, such as the manager or the bareboat charterer, which has assumed the responsibility for the operation of the ship from the shipowner - Art. 3 (1) d) Regulation (EC) No. 2015/757) were obliged to submit to the verifiers (a legal entity carrying out verification activities which is accredited by a national accreditation body pursuant to Regulation (EC) No. 765/2008 and this Regulation - Art. 3(1) f) Regulation (EC) No. 2015/757), by $31^{\text {st }}$ August 2017, a monitoring plan for each of their ships that had to include technical specifications and selected methods for monitoring $\mathrm{CO}_{2}$ emissions from maritime traffic and report them in relation to their ship.

Based on the monitoring plan assessed by the verifier, in accordance with the provision in Art. 8 of Regulation (EC) No. 2015/757, from 1st January 2018, companies are obliged to monitor $\mathrm{CO}_{2}$ emissions for each ship on a pervoyage. Monitoring on a per-voyage basis means that companies shall monitor for each ship arriving in or departing from a port under a Member State's juridiction and for each voyage to or from a port under a Member State's juridiction the following parameters: a) port of departure and port of arrival including the date and hour of departure and arrival; b) amount and emission factor for each type of fuel consumed in total; c) $\mathrm{CO}_{2}$ emitted; d) distance travelled; e) time spent at sea; f) cargo carried; g) transport work (Art. 9(2) Regulation 2015/757). Derogation from these rule presents solution in paragraph 2 of this Article: a company shall be exempt from the obligation to monitor the information referred to in paragrapf 1 of this Article on a per-voyage basis in respect of a specified ship if: a) all of the ship's voyages during the reporting period either start from or end at a port under the jurisdiction of a Member State; and b) the ship, according to her schedule, performs more than 300 voyages during the reporting period (Art. 9.(2) Regulation (EC) No. 2015/757). 
From 1st January 2018, companies are obligated to monitor $\mathrm{CO}_{2}$ emissions also on an annual basis applying the appropriate method for determining $\mathrm{CO}_{2}$ emissions among those set out in Part B of Annex I ("Methods for Determining $\mathrm{CO}_{2}$ Emissions") of Regulation (EC) No. 2015/757. Companies are obligate to calculate $\mathrm{CO}_{2}$ emissions in accordance with Part A of Annex I ("Calculation of $\mathrm{CO}_{2}$ Emissions") of Regulation (EC) No. 2015/757. In order to reduce $\mathrm{CO}_{2}$ emissions from maritime traffic, a measure of establishing a $\mathrm{CO}_{2}$ emissions monitoring system based on fuel consumption of ships has been chosen as the best possible option (including fuel consumed by main engines, auxiliary engines, gas turbines, boilers and inert gas generators). The first three methods relate to the determination of the amount of fuel loaded or the amount of fuel remaining in the stock by converting the volume to the mass with the value of the actual fuel density. It is important to note that for ro-ro passenger ships, carrying cargo and passengers (i.e. providing different transport services), it is necessary to identify the difference between fuel consumption and $\mathrm{CO}_{2}$ emissions for cargo and passengers [28]. To calculate $\mathrm{CO}_{2}$ emissions, the companies use the following formula: fuel consumption $\mathrm{x}$ emission factor. Emission factor means the average emission rate of a greenhouse gas relative to the activity data of a source stream, assuming complete oxidation for combustion and complete conversion for all other chemical reactions (Art.3(1) j) Regulation 2015/757). Emission factors for fuels used on bord are: Diesel/Gas oil - 3.206; Light fuel oil - 3.151; Heavy fuel oil - 3.114; Liquefied petroleum gas (Propane) - 3.000; Liquefied petroleum gas (Butane) - 3.030; Liquefied natural gas - 2.750; Methanol - 1.375; Ethanol - 1.913 [29].

From 2019, by $30^{\text {th }}$ April of each year, the companies shall submit to the Commission and to the authorities of the flag States concerned, an emissions report concerning the $\mathrm{CO}_{2}$ emissions for each ship under their responsibility (Art. 11(1) of Regulation (EC) No. 2015/757). The Commission shall make the above information publicly available by 30 th June each year, especially in relation to the annual $\mathrm{CO}_{2}$ emissions; the annual total fuel consumption for voyages; the annual average fuel consumption and $\mathrm{CO}_{2}$ emissions per distance travelled of voyages: the annual average fuel consumption and $\mathrm{CO}_{2}$ emissions per distance travelled and cargo carried on voyages etc. (Art.21 Regulation (EC) 2015/757). Templates and technical rules for the submission of monitoring plans, emissions reports and documents of compliance pursuant to Regulation (EC) No. 2015/757 are laid down in the Commission Implementing Regulation (EC) No. 2016/1927 of $4^{\text {th }}$ November 2016 on templates for monitoring plans, emissions reports and documents of compliance pursuant to Regulation (EC) No. 2015/757 [30]. Pursuant to the provision of Art. 3 of Regulation (EC) No. 2016/1927, for the purposes of submitting the Emissions Report (from 2019, by $30^{\text {th }}$ April of each year, companies shall submit to the Commission and to the flag States concerned an emissions report), the company is obliged to use the electronic versions of the template of the emissions report in accordance with Annex II ("Template for Emissions Report") of this Regulation. The emissions reports are assessed by the verifier in accordance with the provisions of Regulation (EC) No. 2015/757. If the verifier is satisfied with the submitted report - he issues the Document of Compliance (a document specific to a ship, issued to a company by a verifier, which confirms that that ship has complied with the requirements of this Regulation for a specific reporting period - Art.3(1) h) Regulation (EC) No. 2015/757) to the vessel concerned, which is valid for the period of 18 months after the end of the reporting period. According to solution Art.17(4) Regulation (EC) No. 2015/757, the verifier shall inform the Commission and the authority of the flag State, without delay, of the issuance of any document of compliance according to the data from electronic template of Document of compliance: ship particulars, shipowner details, details of company fulfilling the obligations under Regulation (EC) No. 2015/757 (Annex III "Template for Document of compliance" Regulation (EC) No. 2016/1927).

\section{Application of the Regulation (EC) No. 2015/757 to Ports of Call under the Jurisdiction of EU Member States}

Maritime ports are the starting point of world seafaring and the reference point of maritime navigation. Maritime ports are also the drivers of economic growth [31] and the $\mathrm{EU}$ is dependent on them to maintain trade relations with the rest of the world, as well as internal commercial exchanges [32]. Europe is the region with the highest density of ports in the world (with more than 1200 maritime ports for commercial use), and it is particularly worrying that the current maritime traffic results in $70-100 \%$ of emissions in ports. Maritime navigation in Europe contributes to the creation of $58 \%$ of $\mathrm{CO}_{2}$ emissions in ports and only ten ports with the largest emissions contribute to the creation of as much as $1 / 5$ of total emissions in ports [9]. It is estimated that, by 2050 , emissions in ports will have resulted in 70 million tonnes [9], so it is important to point to the measures aimed at reducing $\mathrm{CO}_{2}$ emissions from maritime traffic.

Since Regulation (EC) No. $2015 / 757$ is fully binding and, with its entry into force on $1^{\text {st }}$ July 2015 , it is directly applicable in the Member States, its provisions are also very important for the ports of the Member States. By determining the operational features of the MRV system and the scope of Regulation (EC) No. 2015/757, it is also laid down in the aforementioned Regulation that the direct $\mathrm{CO}_{2}$ emissions measurements may be used for voyages and for $\mathrm{CO}_{2}$ emissions occurring in ports located in a Member State's jurisdiction. From $1^{\text {st }}$ January 2018, the shipowner or any other organization or person who has assumed responsibility for the operation of the ship from the shipowner has a duty, for the ships above 5000 gross 
tonnage, to monitor, inform, report, and verify the annual emissions of $\mathrm{CO}_{2}$ released during their voyages: A) from their last port of call to a port of call under the jurisdiction of a Member State (therefore duties to monitor, report and verifier of $\mathrm{CO}_{2}$ emissions from ships above 5000 gross tonage applies on $\mathrm{CO}_{2}$ emissions produced during the entire voyage from a non-EU port to an EU port) [33]; B) from a port of call under the jurisdiction of a Member State to their next port of call; and C) within ports of call under the jurisdiction of a Member State [34]. MRV system includes $\mathrm{CO}_{2}$ emissions from ships in ports (when a ship at berth is securely moored or anchored in a port falling under the jurisdiction of a Member State while she is loading, unloading or hotelling, including the time spent when not engaged in cargo operations (Art.3(1) n) Regulation $2015 / 757$ ) and also on a ship in navigation within a port).

Ports of call are important as the starting and end points of the voyage. We note that the European legislator has chosen to use the term port of call, defining it as the port where the ship stops to load or unload cargo or to embark or disembark passengers (Art.3(1) b) of Regulation (EC) No. 2015/757). At the same time, stops for the sole purposes of refuelling, obtaining supplies, relieving the crew, going into dry-dock or making repairs to the ship and/or its equipment, stops in port because the ship is in need of assistance or in distress, ship-to-ship transfers carried out outside ports, and stops for the sole purpose of taking shelter from adverse weather or rendered necessary by search and rescue activities are excluded (Art.3(1) b) Regulation (EC) No. 2015/757). The European legislator has laid down that, for the purposes of monitoring $\mathrm{CO}_{2}$ emissions from maritime traffic, all intra-Union voyages, all incoming voyages from the last non-Union port to the first Union port of call and all outgoing voyages from a Union port to the next non-Union port of call, including ballast voyages, are to be considered relevant. It is important to note that the port of call under the jurisdiction of a Member State means the port of call on the EU territory to which European legislation applies. EU Member States are: Austria, Belgium, Bulgaria, Croatia, Cyprus, Czech Republic, Denmark, Estonia, Finland, France, Germany, Greece, Hungary, Ireland, Italy, Latvia, Lithuania, Luxembourg, Malta, Netherlands, Poland, Portugal, Romania, Slovakia, Slovenia, Spain, Sweden, Unitred Kingdom. The states listed are also members of the European Economic Area - EEA (in addition to 28 EU member states, EEA member states are still Iceland, Lichtenstein and Norway as members of the European Free Trade Association - EFTA).

In order for the provisions of Regulation (EC) No. $2015 / 757$ to apply to a certain voyage, at least one port of call must be in the territory of the EU to which European legislation applies. Ports within the following territories are not considered to be ports of call under the jurisdiction of an EU member states: Greenland and Faroe Islands; French Polynesia; New Caledonia; Saint-Barthélemy; Saint Pierre and Miquelon; Wallis and Futuna; Aruba; Bonaire;
Saba; Sint Eustatius; Curacao; Sint Maarten; Anguilla; Bermuda; British Antartic Territory; British Indian Ocean Territory; British Virgin Islanda; Cayman Islands; Falkland Islands; Bailiwick of Guernsey; Isle of Man; Jersey; Montserrat; Pitcairn; Henderson; Ducie and Oeno Islands; Saint Helena; Ascension and Tristan da Cunna; South Georgia and the South Sandwich Islands; Turks and Caico Islands; Akrotiri and Dhekelia [35]. Ports from the outermost regions of the EU: Azores, Madeira, Canaries, Guadeloupe, French Guiana, Martinique, Saint Martin and Reunion, but also ports in Norway (except Svalbard) and Iceland are considered European ports of call within the meaning of Regulation (EC) No. 2015/757.

\subsection{Enforcement of Obligations Arising from Regulation (EC) No. 2015/757 - Enhancing the Security of Ships and Ports, Compliance with Flag State Requirements and Port State Control}

Ships arriving in ports located in the EU Member States are required to provide information on ship security and safety according to Art.6 Regulation (EC) No. 725/2004 [36]. In order to effectively monitor compliance with the security rules by ships intending to enter a Community port, Regulation (EC) No. 725/2004 provides that ships give information on ship security before entering the port of the EU Member State as soon as the port of call becomes known (if the port of call is not known or it is changed during the voyage). This is an official procedure for reporting information for administrative and procedural purposes under the Directive 2010/65/EC [37]. The purpose of these provisions is to ensure the transmission of data required upon arrival in or departure from EU ports.

Enforcement of the obligations relating to the MRV system should be based on European legal solutions regarding compliance with flag State requirements (Directive 2009/21/EC) [38] and port State control (Directive 2009/16/EC) [39]. In order to ensure that Member States effectively and consistently discharge their obligations as flag States, enhance safety and prevent pollution from ships flying the flag of a Member State - prior to allowing a ship to operate, which has been granted the right to fly its flag, the Member State concerned shall take the measures it deems appropriate to ensure that the ship in question complies with the applicable international rules and regulations (Art.1 Directive 2009/21/EC). Taking into account that,according to Art.8 and 18 Regulation (EC) No. 2015/757, by $30^{\text {th }}$ June of the year following the end of a reporting period (i.e. 2019) - ships above 5000 gross tonnage arriving in or departing from a port under the jurisdiction of a Member State or that are located in it, and which have carried out voyages during that reporting period, have to carry on board a valid Document of Compliance. For all ships entering ports of the Member States and for which certain required information concerning the Document of Compliance is not available, Member States should endeavour to inspect ships [40] [41]. So, as from $1^{\text {st } J u l y ~} 2019$, the ships will have to carry a 
Document of Compliance which can be a subject of verification (inspection) when the ship is in a port. Specifically, to any ship calling at an EU port, apply the provisions of Directive 2009/16/EC, which was adopted in order to drastically reduce substandard ships in the waters under the jurisdiction of Member States. Therefore, it is a required responsibility of the flag State to monitor the compliance of ships with the international standards for pollution prevention and their implementation. The above mentioned obligation is discharged by the flag States, ensuring the completeness and efficiency of inspections. Pursuant to the provision of Art. 10(1) of Directive 2009/16/EC, for all ships calling at a port or anchorage of a Member State, in the inspection database, must be attributed a ship risk profile. The risk profile of a ship shall be determined by a combination of generic and historical risk parameters as follows: Generic parameters (shall be based on the type, age, flag, recognised organisations involved and company performance in accordance with Annex I "Element of the Community Port State Inspection System", Part I 1 - Ship risk profile and and Annex II "Design of Ship risk profile") and Historical parameters (shall be based on the number of deficiencies and detentions during a given period in accordance with Annex I "Element of the Community Port State Inspection System", Part I 2 - Historical parameters and Annex II "Design of Ship risk profile" - Art.10(2) Directive 2009/16/EC. Ship risk profile determines their respective priority for inspection, the intervals between the inspections and the scope of inspections so the competent authority shall ensure that ships are selected for inspection on the basis of their risk profile (Art.12(1) Directive 2009/16/EC). Member States have to ensure that ships which are selected for inspection are subject to an initial inspection by an inspector who checks the certificates and documents listed in Annex IV ("List of Certificates and Documents") required to be kept on board in accordance with Community maritime legislation and Conventions relating to safety and security. Certificates and documents must also include the Document of Compliance issued by a verifier which has to be kept on board ships to demonstrate compliance with the obligations for monitoring, reporting and verification, issued under Regulation (EC) No. 2015/757.

\section{Conclusion}

Traffic accounts for about $14 \%$ of greenhouse gas emissions. $\mathrm{CO}_{2}$ emissions generated as a result of maritime navigation have a $10 \%$ share in global greenhouse gas emissions, right after road transport (74\%) and air transport $(12.6 \%)$. Since $2 / 3$ of international trade is transported by sea - efficient and clean maritime transport has an extremely important role in reducing greenhouse gas emissions and thus also $\mathrm{CO}_{2}$ as the most important greenhouse gas. In order to reduce $\mathrm{CO}_{2}$ emissions from maritime traffic at a cost-effective EU level, Regulation (EC) No. $2015 / 757$ on the monitoring, reporting and verification of $\mathrm{CO}_{2}$ emissions from maritime traffic was adopted. It is a newly established European system for monitoring, reporting and verification of $\mathrm{CO}_{2}$ emissions from maritime traffic (MRV system) applied to ships irrespective of the flag fly, but only when these ships weigh more than 5000 gross tonnes. Although it is not a comprehensive solution to the problem of $\mathrm{CO}_{2}$ emissions from maritime traffic because it does not apply to all ships (irrespective of their gross tonnage) but to only $55 \%$ of ships, i.e. about 15000 ships, it is important to notice that ships weighing more than 5000 gross tonnes are responsible for about $90 \%$ of $\mathrm{CO}_{2}$ emissions. Regulation (EC) No. 2015/757 defines the scope of application in detail, emphasizing the importance and role of European ports of call as ports where a ship stops to load or unload cargo, i.e. to embark or disembark passengers. Specifically, the European legislator provides for the application of Regulation (EC) No. 2015/757 only in respect of ships above 5000 gross tonnage which are arriving in and departing from ports of call under the jurisdiction of Member States or ships at berth in Community ports. It is important to emphasize that Regulation (EC) No. 2015/757 applies to ports of call under the jurisdiction of Member States (to which European law applies), but not to ports of call of the outermost regions of the EEA Member States.

By the end of August 2017, companies (a shipowner or another person who has assumed responsibility for the operation of the ship from the shipowner) were obliged to submit a Monitoring Plan for each of their ships to the verifiers, indicating the method chosen to monitor $\mathrm{CO}_{2}$ emissions. Likewise, as of $1^{\text {st }}$ January 2018, companies are obliged to monitor, for each of their ships, $\mathrm{CO}_{2}$ emissions from maritime navigation. Given that the enforcement of obligations deriving from the established MRV system at European level should also be based on the application of other European legal standards, relevant provisions regarding compliance with the flag State requirements and provisions on port State control have also been analyzed, including the inspection of the ship in a port given the existence of the Document of Compliance of the ship with the obligations arising from Regulation (EC) No. 2015/757. Namely, from $1^{\text {st }}$ July 2019 , all ships will have to carry a Document of Compliance when arriving in or departing from the European port of call of the Member States and to which the European legislation applies. The legal framework established by Regulation (EC) No. 2015/757 has been extended by Regulation (EC) No. 2016/192, Regulation (EC) No. 2016/1928 and delegated Regulation (EC) No. 2016/2071, which complement the rules and methods of monitoring $\mathrm{CO}_{2}$ emissions from maritime transport by systematically regulating MRV maritime legislation.

By encouraging international trade and the achievement of a low-carbon economy, it is estimated that the introduction of the MRV system will encourage emission reductions of up to $2 \%$ compared to business-as-usual, and aggregated net costs reductions of up to EUR 1,2 bil- 
lion by 2030 [42], thus having an effect on the reduction of transport costs [43] [44]. However, the professional public objects to these unilateral measures at European level, stressing that the provisions of Regulation (EC) No. 2015/757 apply also to ships that do not fly the flag of a Member State, and which are either arriving in or departing from ports of call of the Member States. Likewise, there are significant objections to the current MRV system, as the application presents a large administrative burden on shipowners or other persons who have assumed responsibility for the operation of the ship from the shipowner [45]. In the interest of achieving the global target, i.e. reducing $\mathrm{CO}_{2}$ emissions, in international shipping, we argue for unification and international legal standards because the global character of maritime shipping requires an international legal system and international uniformity.

\section{References}

[1] Shipping and World Trade, http://www.ics-shipping.org/ shipping-facts/shipping-and-world-trade (last visited: 12.10.2017).

[2] https://ec.europa.eu/transport/modes/maritime/ports/ ports_en (last visited: 03.09.2017).

[3] Shi, Y.: Reducing greenhouse gas emissions from international shipping: Is it time to consider marked-based measures?, Marine Policy, vol. 64, 2016, pp. 123-134.

[4] Schrooten, L., De Vlieger, I., Int Panis,L.: Emissions of maritime transport: A European reference system, Science of the Total Environment, vol. 48, no. 2, 2009, pp. 318-323.

[5] A European Strategy for low - emission mobility, https:// ec.europa.eu/clima/policies/transport_en (last visited: 10.10.2017).

[6] Gritsenko, D.: Regulating GHG Emissions from shipping: Local, global, or polycentric approach? Marine Policy, vol. 84, 2017, pp. 130-133.

[7] Zanne, M., Twrdy, E.: Air pollution from maritime transport - the problem of Today, the challenges of Tommorow, Pomorstvo, Rijeka, vol. 25, no. 1, 2011, p. 106.

[8] Delbeke, J., Klaassen, G., Vergote, S.: Climate -related energy policies, in: EU Climate Policy, Routledge, 2015, p. 84.

[9] Merk, O.: Shipping Emissions in Ports, International Transport Forum, Discussion Paper 2014, pp. 4, 6, 19, https:// www.itf-oecd.org/sites/default/files/docs/dp201420.pdf (last visited: 23.10.2017).

[10] GHG emission reduction potential of EU-related maritime transport and on its impacts, TNO 2014 R11601 Final, 2015, p.16, https: report_ghg_reduction_potential_en.pd (last visited: 23.10.2017).

[11] 2030 Energy Strategy, https://ec.europa.eu/energy/en/ topics/energy-strategy-and-energy-union/2030-energystrateg (last visited: 25.10.2017).

[12] Global Greenhouse Gas Emissions Data, 2014, https:// www.epa.gov/ghgemissions/global-greenhouse-gas-emissions-data (last visited: 26.10.2017).

[13] Brozović I., Regent, A., Grgurević, M.: Greenhouse gas emissions, especially from traffic, Journal of the Polytechnic of Rijeka, vol. 2, no. 1, 2014, p. 278.

[14] Regulation (EC) No. 525/2013 of the European Parliament and of the Council of 21 May 2013 on a mechanism for monitoring and reporting greenhouse gas emissions and for reporting other information at national and Union level relevant to climate change), OJ L 165, 18.6.2013, p. 13-40.

[15] Reducing emissions from shipping sector, European Comission, 2017, p.1, https://ec.europa.eu/clima/policies/transport/shipping_en (last visited: 05.11.2017).

[16] IMO Study on GHG Emissions from Ships, MEPC 45/8, June 2000.

[17] Second IMO GHG Study 2009, http://www.imo.org/en/ OurWork/Environment/PollutionPrevention/AirPollution/ Documents/SecondIMOGHGStudy2009.pdf (last visited: 5.11.2017).

[18] Third IMO GHG Study 2014, p.32, http://www.imo.org/en/ OurWork/Environment/PollutionPrevention/AirPollution/ Documents/Third\%20Greenhouse\%20Gas\%20Study/ GHG3\%20Executive\%20Summary\%20and\%20Report.pdf (last visited: 20.10.2017).

[19] Dulebenets, M. A.: Green Vessel Scheduling in Liner Shipping: Modeling Carbon Emission Costs in Sea and at Ports of Call, International Journal of Transportation Science and Technology, 2017, p. 1.

[20] Integrating maritime transport emissions in the EU's greenhouse gas reduction policies, Comunication from the Commission to the European Parliament, the Council, the European Economic and Social Committee and the Committee of the Regions, COM(2013) 479 final, Brussels, 28.6.2013, p. 2, https://ec.europa.eu/clima/sites/clima/ files/transport/shipping/docs/com_2013_479_en.pdf (last visited: 19.10.2017).

[21] Popek, M.: Response of international shipping to the current environmental challenges, 1st International Conference on the Sustainable Energy and Environment - SEED 2016, vol. 10, p. 3, available on https://www.e3s-conferences.org/articles/e3sconf/pdf/2016/05/e3sconf_seed2016_00075.pdf (last visited: 19.09.2017).

[22] The EU 2011 White Paper on Transport-White Paper Roadmap to Single European Transport Area -towards a competitive and resources efficient transport system, COM/2011/0144 final, pp. 1-31, eur-lex.europa.eu/legalcontent/EN/ALL/?uri=CELEX:52011DC0144 (last visited: 19.09.2017).

[23] Psaraftis, H. N.: Green maritime logistics: the quest for winwin solutions, Transportation Research Procedia, vol. 14, 2016, p. 135.

[24] Regulation (EC) No. 2015/757 of the European Parliament and of the Council of 29 April 2015 on the monitoring, reporting and verification of carbon dioxide emissions from maritime transport, amending Directive 2009/16/EC, OJ L 123, 19.5.2015, pp. 55-76.

[25] Fedi, L.: The Monitoring, Reporting and Verification of Ships' Carbon Dioxide Emissions: A European Substantial Policy Measure towards Accurate and Transparent Carbon Dioxide Quantification, Ocean Yearbook Online, vol. 31, no. 1, 2017, pp. 381-417.

[26] Rehmatulla, N., Calleya, J., Smith, T.: The implementation of technical energy efficiency and $\mathrm{CO}_{2}$ emission reduction measures in shipping, Ocean Engineering, vol. 139, 2017, p. 185.

[27] Johansson, L., Jalkanen, J. P., Kukkonen, J.: Global assessment of shipping emissions in 2015 on a high spatial and temporal resolution, Atmospheric Environment, vol. 167, 2017, pp. 409-410. 
[28] Commission implementing Regulation (EC) No. 2016/1928 of 4 November 2016 on determination of cargo carried for categories of ships other than passenger, ro-ro and container ships pursuant Regulation (EC) No. 2015/757 of the European Parliament and of the Council on the monitoring, reporting and verification of carbon dioxide emissions from maritime transport), OJ L 299, 5.11.2016, pp. 22-25.

[29] Commission delegated Regulation (EC) No. 2016/2071 of 22 September 2016 amending Regulation (EC) No. 2015/757 of the European Parliament and of the Council as regards the method for monitoring carbon dioxide emissions and the rules for monitoring other relevant information, OJ, L 320, 26.11.2016, pp. 1-4.

[30] Commission implementing Regulation (EC) No. 2016/ 1927 of 4 November 2016 on templates for monitoring plans, emissions reports and documents of compliance pursuant to Regulation (EC) No. 2015/757 of the European Parliament and of the Council of 29 April 2015 on the monitoring, reporting and verification of carbon dioxide emissions from maritime transport),0J L 299, 5.11.2016, pp. 1-21.

[31] Lonza, L., Marolda, C.: Ports as drivers of urban and regional growth, Transportation Research Procedia, no. 14, 2016, pp. 2508-2509.

[32] Communication from the Commission Ports: an engine for growth, COM/2013/0295 final, p.3, http://eur-lex.europa. eu/legal-content/EN/ALL/?uri=COM:2013:0295:FIN (last visited: 02.09.2017).

[33] Ryngaert, C., Ringbom, H.: Introduction: Port State Jurisdiction; Challenges and Potential, The International Journal of Marine and Coastal Law, vol. 31, no. 1, 2016, p. 393.

[34] Styhre, L., Winnes, H., Black, J.; Lee, J., Le-Griffin, H.: Greenhouse gas emissions from ships in ports - Case studies in four continents, Transportation Research Part D: Transport and Environment, vol. 54, 2017, pp. 212-224.

[35] Guidelines for ships over 5000GT which carry passengers or cargo to, from or between EU/EEA ports, regardless of Flag, International Chamber of shipping, p.3, http://www. ics-shipping.org/docs/default-source/resources/ics-guidance-on-eu-mrv.pdf?sfvrsn=8 (last visited: 10.11.2017).
[36] Regulation (EC) No. 725/2004 of the European Parliament and of the Council of 31 March 2004 on enhancing ship and port facility security), OJ L 129, 29.4.2004, pp. 6-91.

[37] Directive 2010/65/EC of the European Parliament and of the Council of 20 October 2010 on reporting formalities for ships arriving in and/or departing from ports of the Member States, OJ L 283, 29.10.2010, pp. 1-10.

[38] Directive 2009/21/EC of the European Parliament and of the Council of 23 April 2009 on compliance with flag State requirements, OJ L 131, 28.5.2009, pp. 132-135.

[39] Directive 2009/16/EC of the European Parliament and of the Council of 23 April 2009 on port State control, OJ L 131, 28.5.2009, pp. 57-100.

[40] Marten, B.: Port State Jurisdiction over Vessel Information: Territoriality, Extra-territoriality and the Future of Shipping Regulation, The International Journal of Marine and Coastal Law, vol. 31, no. 3, 2016, pp. 470-498.

[41] Churchill, R.: Port State Jurisdiction Relating to the Safety of Shipping and Pollution from Ships - What Degree of Extra-territoriality?, The International Journal of Marine and Coastal Law, vol. 31, no. 3, 2016, pp. 442-469.

[42] Position of the Council at first reading with to the adoption of a Regulation of the European Parliament and of the Council on the monitoring, reporting and verification of carbon dioxide emissions from maritime transport, and amending Directive 2009/16/EC, 2013/0224 (COD), Bruxelles, 26 February 2015, p. 7, http://data.consilium.europa.eu/doc/document/ ST-17086-2014-INIT/hr/pdf (last visited: 01.10.2017).

[43] Lindstad, H., Asbjørnslett, B. E.; Strømman, A. H.: The importance of economies of scale for reductions in greenhouse gas emissions from shipping, Energy Policy, vol. 46, 2012, pp. 386-398.

[44] Yuan, J., Hui Ng, S., Sut Sou, W.: Uncertainty quantification of $\mathrm{CO}_{2}$ emission reduction for maritime shipping, Energy Policy, vol. 88, 2016, pp. 113-130.

[45] Watson F. \& Williams: Briefing - Carbon dioxide emission from maritime transport, August 2015, p. 4, http://www. wfw.com/wp-content/uploads/2015/08/WFW-CarbonDioxideEmissionsFromMaritimeTransport.pdf (last visited: 117.10.2017). 